\title{
Philadelphia-negative chromosomal evolution during treatment for chronic myeloid leukemia
}

\author{
H.-H. Hsiao ${ }^{1,2,3}$, Y.-C. Liu ${ }^{1,2,3}$, C.-P. Lee ${ }^{1}$, C.-S. Chang ${ }^{1,2}$ and S.-F. Lin ${ }^{1,2,3}$ \\ ${ }^{1}$ Faculty of Medicine, Kaohsiung Medical University, Taiwan \\ ${ }^{2}$ Graduate Institute of Medicine, College of Medicine, \\ Kaohsiung Medical University, Kaohsiung, Taiwan \\ ${ }^{3}$ Department of Internal Medicine, Division of Hematology-Oncology, \\ Kaohsiung Medical University Hospital, Kaohsiung, Taiwan \\ Corresponding author: S.-F. Lin \\ E-mail: shlin@cc.kmu.edu.tw
}

Genet. Mol. Res. 11 (1): 317-321 (2012)

Received June 13, 2011

Accepted July 12, 2011

Published February 10, 2012

DOI http://dx.doi.org/10.4238/2012.February.10.2

\begin{abstract}
Chromosome evolution is one of the major mechanisms of disease progression and resistance in chronic myeloid leukemia (CML) patients. However, the clinical significance of chromosomal evolution in the Philadelphia $(\mathrm{Ph})$-negative clone during therapy is not fully understood. We evaluated $94 \mathrm{CML}$ patients in the chronic phase of CML during treatment of the disease. Six of them had Ph-negative chromosome abnormalities during treatment. Four patients with a single abnormality and a good molecular response showed no obvious complications from the chromosomal changes, while two other patients who had complex abnormalities and previous treatment had poor outcomes. Our results highlight the need for close monitoring of this kind of patient, not only on a molecular level but also at the cytogenetic level.
\end{abstract}

Key words: Chronic myeloid leukemia; Philadelphia chromosome; Chromosome evolution 


\section{INTRODUCTION}

Chronic myeloid leukemia (CML) is a clonal hematopoietic stem cell disorder characterized by the proliferation of the myeloid series and the presence of the Philadelphia $(\mathrm{Ph})$ chromosome and BCR-ABL fusion genes. Before the era of selective tyrosine kinase inhibitors, hydroxyurea, interferon, cytosine arabinoside, or hematopoietic stem cell transplantation were treatment choices for the management of CML for eligible patients. Recently, a great advanced in CML treatment has been noted after the introduction of imatinib mesylate, a selective tyrosine kinase inhibitor, with a complete hematologic response of $95 \%$ and complete cytogenetic response of $75 \%$ in chronic phase patients (O'Brien et al., 2003).

However, a subset of patients has been found to develop clonal evolution in Ph-negative cells during the management of CML (Loriaux and Deininger, 2004; Terre et al., 2004). The clinical significance and real pathomechanism of this phenomenon are not fully understood. We evaluated the series changes of chromosome abnormalities in the Ph-negative clone during therapy for CML.

\section{MATERIAL AND METHODS}

From 2000 to 2010, 94 patients with CML in the chronic phase were treated and enrolled in the study after informed consent. The diagnosis of CML was established on the basis of bone marrow examination, supported by cytogenetic and molecular studies and low leukocyte alkaline phosphatase activity. Clinical presentations and laboratory data were retrospectively collected from the medical records.

\section{Cytogenetic and molecular studies}

Cytogenetic and molecular studies were performed in the diagnosis and follow-up. Cytogenetic studies were carried out on bone marrow samples, and the study was performed with unstimulated specimens by the Giemsa-banding method. The results were identified according to the Human System for Cytogenetic Nomenclature (ISCN). The bone marrow samples were also used for the molecular studies. RNA was extracted from Ficoll-separated mononuclear cells from the bone marrow specimens. The products were used for the diagnosis of the $B C R-A B L$ gene and also in quantitative RT-PCR for molecular response analysis.

\section{RESULTS}

In the median follow-up of 68 months for all 94 patients, 6 patients (6.4\%) had Ph-negative chromosome abnormalities during the treatment courses for CML (Table 1). Two of them were exposed to imatinib only (cases 1 and 2); while the other 4 patients had previous therapy with hydroxyurea and even stem cell transplantation (SCT) (case 6). The median follow-up of these 6 cases was 62 months from diagnosis, and the median duration from the use of imatinib to the occurrence of Ph-negative abnormalities was 11.5 months. Cases 1 to 4 had a single abnormality in the Ph-negative clone and showed a benign course of the disease. There were no obvious changes in the peripheral blood counts and no dysplastic pictures in the bone marrow examinations. All of these 4 patients had a low level of $B C R-A B L$ during the appearance 
of abnormal clones, and all of them had a disappearance of abnormal clones in the follow-up examinations. They are all alive to date with continuous imatinib therapy.

\begin{tabular}{|c|c|c|c|c|c|c|c|}
\hline Case & Age/gender & Status & $\begin{array}{l}\text { Time from } \\
\text { diagnosis } \\
\text { (months) }\end{array}$ & $\begin{array}{l}\text { Time with } \\
\text { imatinib } \\
\text { (months) }\end{array}$ & Cytogenetics & $\begin{array}{l}\text { Molecular response } \\
\text { (log reduction) }\end{array}$ & Treatment \\
\hline \multirow[t]{5}{*}{1} & $48 / \mathrm{F}$ & $\mathrm{CP}$ & 0 & 0 & $46, \mathrm{XX}, \mathrm{t}(9 ; 22)(\mathrm{q} 34 ; \mathrm{q} 11.2)[7]$ & & \\
\hline & & $\mathrm{CP}$ & 4 & 4 & $\begin{array}{l}\text { 46,XX,t(9;22)(q34;q11.2)[1]/43,XX } \\
-\mathbf{- 7 , + 8 , - 1 5 , - 1 7 , - 2 0 [ 1 ] / 4 6 , X X [ 2 ] ~}\end{array}$ & 1.17 & IM 400 \\
\hline & & $\mathrm{CP}$ & 6 & 6 & 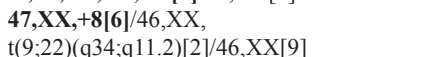 & 2.35 & IM 400 \\
\hline & & $\mathrm{CP}$ & 12 & 12 & $47, \mathbf{X X},+8[14] / 46, X X[1]$ & 3.96 & IM 400 \\
\hline & & $\mathrm{CP}$ & 24 & 24 & $46, \mathrm{XX}[20]$ & Undetectable & IM 400 \\
\hline \multirow[t]{5}{*}{2} & $71 / \mathrm{M}$ & $\mathrm{CP}$ & 0 & 0 & 46,XY,t(9;22)(q34;q11)[20] & & IM 400 \\
\hline & & $\mathrm{CP}$ & 3 & 3 & $46, \mathrm{XY}, \mathrm{t}(9 ; 22)(\mathrm{q} 34 ; \mathrm{q} 11)[3] / 46, \mathrm{XY}[16]$ & 1.52 & IM 400 \\
\hline & & $\mathrm{CP}$ & 10 & 10 & $45, X,-Y[7] / 46, X Y[13]$ & 3.95 & IM 300 \\
\hline & & $\mathrm{CP}$ & 36 & 36 & $45, X,-Y[4] / 46, X Y[16]$ & Undetectable & IM 300 \\
\hline & & $\mathrm{CP}$ & 50 & 50 & $46, X Y[19]$ & Undetectable & IM 300 \\
\hline \multirow[t]{5}{*}{3} & $58 / \mathrm{F}$ & $\mathrm{CP}$ & 0 & 0 & $46, \mathrm{XX}, \mathrm{t}(9 ; 22)(\mathrm{q} 34 ; \mathrm{q} 11.2)[20]$ & & $\mathrm{HX}$ \\
\hline & & $\mathrm{CP}$ & 30 & 0 & $46, \mathrm{XY}, \mathrm{t}(9 ; 22)(\mathrm{q} 34 ; \mathrm{q} 11.2)[8]$ & 0.27 & IM 400 \\
\hline & & $\mathrm{CP}$ & 37 & 7 & $47, \mathbf{X X},+8[2] / 46, X X[18]$ & 3.54 & IM 400 \\
\hline & & $\mathrm{CP}$ & 66 & 36 & $46, X X[19]$ & Undetectable & IM 400 \\
\hline & & $\mathrm{CP}$ & 78 & 48 & $46, \mathrm{XX}[20]$ & Undetectable & IM 400 \\
\hline \multirow[t]{5}{*}{4} & $34 / \mathrm{M}$ & $\mathrm{CP}$ & 0 & 0 & $46, \mathrm{XX}, \mathrm{t}(9 ; 22)(\mathrm{q} 34 ; \mathrm{q} 11.2)[20]$ & & $\mathrm{HX}$ \\
\hline & & $\mathrm{CP}$ & 13 & 9 & $46, \mathrm{XY}[20]$ & & IM 400 \\
\hline & & $\mathrm{CP}$ & 25 & 21 & 46,XY,t(6;9)(p11;p11)[3]/46,XY[16] & & IM 400 \\
\hline & & $\mathrm{CP}$ & 38 & 34 & $46, \mathrm{XY}[20]$ & & IM 400 \\
\hline & & $\mathrm{CP}$ & 72 & 68 & $46, X Y[20]$ & Undetectable & IM 400 \\
\hline \multirow[t]{7}{*}{5} & $60 / \mathrm{M}$ & $\mathrm{CP}$ & 0 & 0 & $46, \mathrm{XY}, \mathrm{t}(9 ; 22)(\mathrm{q} 34 ; \mathrm{q} 11)[10]$ & & HX \\
\hline & & $\mathrm{CP}$ & 16 & 0 & $46, \mathrm{XY}, \mathrm{t}(9 ; 22)(\mathrm{q} 34 ; \mathrm{q} 11.2)[20]$ & & IM 200 \\
\hline & & $\mathrm{CP}$ & 29 & 13 & $46, \mathrm{XY}, \mathrm{t}(9 ; 22)(\mathrm{q} 34 ; \mathrm{q} 11.2)[8] / \mathbf{4 7 , X Y}, \mathbf{8}[\mathbf{3}]$ & 1.55 & IM 400 \\
\hline & & $\mathrm{CP}$ & 38 & 22 & $\begin{array}{l}46 \sim 48, \mathrm{XY},+8, \mathrm{t}(9 ; 22)(\mathrm{q} 34 ; \mathrm{q} 11.2),-16, \\
\mathrm{i}(17)(\mathrm{g} 10),+\operatorname{der}(22) \mathrm{t}(9 ; 22)(\mathrm{q} 34 ; \mathrm{q} 11.2)[10]\end{array}$ & Failed & IM 400 \\
\hline & & $\mathrm{BC}$ & 43 & 27 & $\begin{array}{l}48, \mathrm{XY},+8, \mathrm{t}(9 ; 22)(\mathrm{q} 34 ; \mathrm{q} 11.2), \mathrm{i}(17),+\operatorname{der}(22) \\
\mathrm{t}(9 ; 22)(\mathrm{q} 34 ; \mathrm{q} 11.2)[18] / 49, \mathrm{XY}, \mathrm{idem},+8[3]\end{array}$ & 0.11 & NI 800 \\
\hline & & $\mathrm{CP}$ & 49 & & $\begin{array}{l}44-48, \mathrm{XY}, \operatorname{der}(7),+8, \mathrm{t}(9 ; 22)(\mathrm{q} 34 ; \mathrm{q} 11.2) \\
\mathrm{i}(17),+\operatorname{der}(22) \mathrm{t}(9 ; 22)(\mathrm{q} 34 ; \mathrm{q} 11.2)[20]\end{array}$ & 0.25 & NI 800 \\
\hline & & $\mathrm{BC}$ & 52 & & 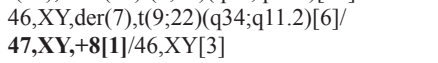 & 0.32 & DA 100 \\
\hline \multirow[t]{9}{*}{6} & $22 / \mathrm{F}$ & $\mathrm{CP}$ & 0 & 0 & $46, \mathrm{XX}, \mathrm{t}(9 ; 22)(\mathrm{q} 34 ; \mathrm{q} 11)[15]$ & & SCT \\
\hline & & $\mathrm{CP}$ & 21 & 0 & $46, \mathrm{XX}[20]$ & & After SCT \\
\hline & & $\mathrm{BC}$ & 66 & 0 & $\begin{array}{l}\text { 47,XX,der(6)t(x;6)(q10;p?),t(9;22)(q34; } \\
\mathrm{q} 11.2), \mathrm{i}(17)(\mathrm{q} 10),+19[20] / 46, \mathrm{XX}[2]\end{array}$ & 0.05 & IM 400 \\
\hline & & $\mathrm{CP}$ & 69 & 3 & $\begin{array}{l}47, \mathrm{XX}, \operatorname{der}(6) \mathrm{t}(\mathrm{x} ; 6)(\mathrm{q} 10 ; \mathrm{p} ?), \mathrm{t}(9 ; 22)(\mathrm{q} 34 ; \\
\mathrm{q} 11.2), \mathrm{i}(17)(\mathrm{q} 10),+19[5] / 46, \mathrm{XX}[3]\end{array}$ & 1.18 & IM 400 \\
\hline & & $\mathrm{CP}$ & 74 & 8 & $46, \mathrm{XX}[13]$ & 2.54 & Before 2nd SCT \\
\hline & & $\mathrm{CP}$ & 78 & 12 & $46, \mathrm{XX}[7]$ & 3.27 & IM 400 \\
\hline & & $\mathrm{CP}$ & 81 & 15 & $\begin{array}{l}46, \mathbf{X X}, \mathbf{t}(1 ; 12)[2] / 45, \mathrm{XX}, \mathrm{t}(3 ; 4)(\mathrm{q} 28 ; q 13), \\
-17[1] / 45, \mathrm{XX},-17[1] / 46, \mathrm{XX}[18]\end{array}$ & 3.86 & IM 400 \\
\hline & & AP & 85 & 19 & 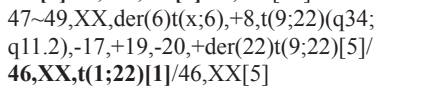 & 0.66 & DA 100 \\
\hline & & $\mathrm{BC}$ & 90 & & $\begin{array}{l}\text { 48 50,XX,der(6)t(x;6), }+8, \mathrm{t}(9 ; 22)(\mathrm{q} 34 ; \\
\mathrm{q} 11.2),-17,+19,-20,+\operatorname{der}(22) \mathrm{t}(9 ; 22)[18]\end{array}$ & 0.21 & NI 800 \\
\hline
\end{tabular}

$\mathrm{AP}=$ accelerated phase $; \mathrm{BC}=$ blast crisis $\mathrm{CP}=$ chronic phase $\mathrm{DA}=$ dasatinib $\mathrm{HX}=$ hydroxyurea $\mathrm{IM}=$ imatinib; $\mathrm{NI}=$ nilotinib; $\mathrm{SCT}=$ stem cell transplantation. Bold data are Ph-negative chromosome abnormalities from other chromosome patterns. 
In contrast, 2 patients (cases 5 and 6) had poor outcomes with disease progression. In case 5, the chromosome abnormalities occurred after previous hydroxyurea therapy and imatinib therapy. Trisomy 8 occurred in the Ph-negative clone followed by clonal evolution in $\mathrm{Ph}$ cells. Although the patient shifted to second-generation target therapy, including nilotinib and dasatinib, no obvious cytogenetic or molecular response was noted. He died of disease progression.

Case 6 was a female who received sibling-matched SCT soon after diagnosis. Unfortunately, a relapse of the disease was noted 5 years later with complex chromosomal abnormalities. She responded well to imatinib and achieved a complete cytogenetic response before the second SCT with an unrelated matched donor. No full donor chimerism or positive results of $B C R-A B L$ were noted after the second SCT and she continued to receive imatinib. $\mathrm{Ph}$-negative chromosome abnormalities were noted during imatinib therapy with a good molecular response. However, the disease rapidly progressed with the loss of both cytogenetic and molecular responses soon after. She responded poorly to second-generation target therapy and expired due to sepsis.

\section{DISCUSSION}

According to previous studies, $4-15 \%$ of patients experience Ph-negative chromosome abnormalities during the management of CML (Andersen et al., 2002; Terre et al., 2004; Deininger et al., 2007). Many abnormalities, including trisomy 8, monosomy 7, nullisomy Y, and other structural aberrations, have been reported to be involved in this kind of change. Most of the patients with such abnormalities demonstrate a benign course of the disease with these abnormalities; however, some cases suffer from transformation of the disease (Kovitz et al., 2006; Lin et al., 2006; Kim et al., 2008).

In our study, we showed that $6.4 \%$ of patients had Ph-negative chromosome abnormalities, which is similar to previous reports (Terre et al., 2004; Deininger et al., 2007). Patients with a single abnormality in our study had benign presentations and most of the abnormalities disappeared in the follow-up, which indicated that the abnormality could be a transient phenomenon (Kim et al., 2008). However, two cases with complex abnormalities and a long history of treatment showed progressive disease and poor molecular response. In these two patients, one had a history of long-term hydroxyurea therapy and the other had previous SCT. The history of heavy treatment in these cases could support the hypothesis that previous cytotoxic agents can contribute to chromosome abnormalities in $\mathrm{Ph}$-negative clones (Bumm et al., 2003).

The other hypothesis of clonal evolution suggests that imatinib, with the ability to inhibit $A B L$ activity, may have a negative effect on DNA repair (Kharbanda et al., 1997; Fabarius et al., 2005). The third hypothesis stresses that the innate genetic instability of CML marrow may cause the development of chromosomal evolution (Tanaka et al., 2004). Since the fact that most of our cases continued on imatinib therapy during the occurrence of $\mathrm{Ph}$ negative abnormality and many of the abnormalities disappeared on imatinib therapy, as shown in other reports, our data, at least, did not favor the theory that imatinib alone could contribute to the abnormalities.

No matter whether the abnormalities come from previous treatment, imatinib therapy, innate instability, or interaction of these causes, most of patients show no obvious effect on 
prognosis (Deininger et al., 2007; Kim et al., 2008). However, as reported here, some cases did progress, and thus, there should be close monitoring, not only on the molecular level but also on the cytogenetic level.

In summary, we present here 6 cases with Ph-negative chromosomal abnormalities during therapy for CML. Although most of them showed no obvious complications from the chromosomal abnormalities, two cases with complex abnormalities and previous treatment had poor outcomes. The results highlight the need for close monitoring of CML patients not only on the molecular but also cytogenetic level.

\section{REFERENCES}

Andersen MK, Pedersen-Bjergaard J, Kjeldsen L, Dufva IH, et al. (2002). Clonal Ph-negative hematopoiesis in CML after therapy with imatinib mesylate is frequently characterized by trisomy 8. Leukemia 16: 1390-1393.

Bumm T, Muller C, Al-Ali HK, Krohn K, et al. (2003). Emergence of clonal cytogenetic abnormalities in Ph- cells in some CML patients in cytogenetic remission to imatinib but restoration of polyclonal hematopoiesis in the majority. Blood 101: 1941-1949.

Deininger MW, Cortes J, Paquette R, Park B, et al. (2007). The prognosis for patients with chronic myeloid leukemia who have clonal cytogenetic abnormalities in Philadelphia chromosome-negative cells. Cancer 110: 1509-1519.

Fabarius A, Giehl M, Frank O, Duesberg P, et al. (2005). Induction of centrosome and chromosome aberrations by imatinib in vitro. Leukemia 19: 1573-1578.

Kharbanda S, Pandey P, Jin S, Inoue S, et al. (1997). Functional interaction between DNA-PK and c-Abl in response to DNA damage. Nature 386: 732-735.

Kim M, Lee S, Jung CK, Lim J, et al. (2008). Transient trisomy 8 abnormality in Philadelphia-negative cells during imatinib mesylate treatment of chronic myelogenous leukemia. Int. J. Lab. Hematol. 30: 508-512.

Kovitz C, Kantarjian H, Garcia-Manero G, Abruzzo LV, et al. (2006). Myelodysplastic syndromes and acute leukemia developing after imatinib mesylate therapy for chronic myeloid leukemia. Blood 108: 2811-2813.

Lin Y, Bruyere H, Horsman DE, Pantzar T, et al. (2006). Philadelphia-negative clonal hematopoiesis following imatinib therapy in patients with chronic myeloid leukemia: a report of nine cases and analysis of predictive factors. Cancer Genet. Cytogenet. 170: 16-23.

Loriaux M and Deininger M (2004). Clonal cytogenetic abnormalities in Philadelphia chromosome negative cells in chronic myeloid leukemia patients treated with imatinib. Leuk. Lymphoma 45: 2197-2203.

O’Brien SG, Guilhot F, Larson RA, Gathmann I, et al. (2003). Imatinib compared with interferon and low-dose cytarabine for newly diagnosed chronic-phase chronic myeloid leukemia. N. Engl. J. Med. 348: 994-1004.

Tanaka H, Tanaka K, Oguma N, Ito K, et al. (2004). Effect of interferon-alpha on chromosome abnormalities in treated chronic myelogenous leukemia patients. Cancer Genet. Cytogenet. 153: 133-143.

Terre C, Eclache V, Rousselot P, Imbert M, et al. (2004). Report of 34 patients with clonal chromosomal abnormalities in Philadelphia-negative cells during imatinib treatment of Philadelphia-positive chronic myeloid leukemia. Leukemia 18: $1340-1346$ 